\section{A Guide to Community Solar: Utility, Private, and Non-profit Project Development}

\section{A new publication that provides options, examples, and legal and financial considerations for community solar projects}

Community solar is a way for multiple individuals to share in the benefits of a single solar installation. The term refers to the pooling of resources to develop a community-scale solar energy project that provides the benefits of solar energy to a group or neighborhood. Renters, condo owners, and homeowners with shading or other issues that prevent them from installing solar energy systems on their own properties are among those who can directly benefit from community solar.

A Guide to Community Solar: Utility, Private, and Nonprofit Project Development is a new publication that helps to evaluate the options available for community solar and navigate the way to a successful installation.

The guide explores the range of incentives and policies available to assist communities with planning and implementing successful local energy projects. Examples are provided of community solar projects in operation, and policy best practices are highlighted.

This informational resource was developed for:

- Project Sponsors - utilities, businesses, community organizations

- Project Participants - investors, utility customers

- Policy Makers

The guide was developed by the National Renewable Energy Laboratory (NREL) in partnership with the Bonneville Environmental Foundation, Northwest Sustainable Energy for Economic Development (Northwest SEED), Stoel Rives, LLP, and Keyes and Fox, LLP (on behalf of IREC). This report was made possible through funding from the U.S. Department of Energy's Solar America Communities program. To learn more, please visit wWw.solaramericacommunities.energy.gov.

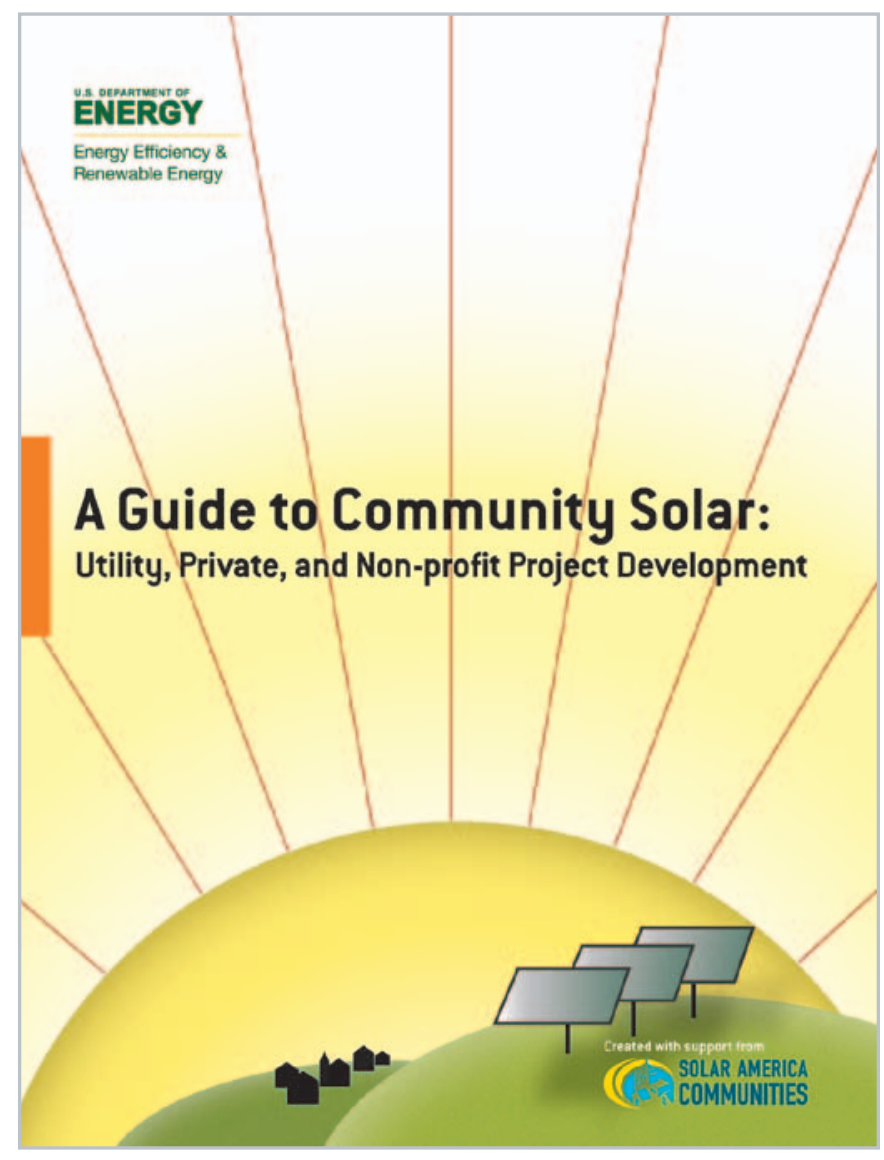

What's Inside:

- $\quad$ Project Sponsorship Models

- $\quad$ Emerging State Policies

- Tax Policies and Incentives

- Securities Issues

- Project Planning Support

- Getting Started

- Resources List

Download the guide at:

WWW.SOLARAMERICACOMMUNITIES.ENERGY.GOV
U.S. DEPARTMENT OF ENROY

Energy Efficiency \& Renewable Energy
EERE Information Center

1-877-EERE-INFO (1-877-337-3463)

www.eere.energy.gov/informationcenter

DOE/GO-102011-3244 • March 2011

Printed with a renewable-source ink on paper containing at least $50 \%$ wastepaper, including $10 \%$ post consumer waste.
Prepared by the National Renewable Energy Laboratory (NREL) NREL is a national laboratory of the U.S. Department of Energy Office of Energy Efficiency and Renewable Energy Operated by the Alliance for Sustainable Energy, LLC 